\title{
Identification of Damage Level and Cost Estimate of Building Maintenance of Elementary School
}

\author{
Fahirah Fahruddin ${ }^{1 *}$, Donny M Mangitung ${ }^{1}$, and Andi Rizal ${ }^{1}$ \\ ${ }^{1}$ Department of Civil Engineering, Engineering Faculty, Tadulako University, Palu
}

\begin{abstract}
The damage of the buildings is a sure thing to happen, in the planning period, implementation until the time of its used. To maintain the reliability of the building and facilities of infrastructure so that the building is always functional, then the building maintenance is done. Cleaning, weeding, testing, repair and / or replacement of building materials or equipment are included in the scope of building maintenance (preventive maintenance). The purpose of this research is to determine the level of damage and cost estimate of building maintenance of elementary school in North Morowali District. The research method used consisted of several stages, namely primary and secondary data collection. Primary data through direct survey to the location and interview with related parties. There are 5 (five) school buildings in North Morowali District. Data processing is done by calculating the damage quantity, the level of damage in the school buildings and cost estimate maintenance. Data analysis was used Descriptive Statistics. The results of the study identified the level of damage from 5 school buildings with an average of minor damage was $21.26 \%$. Cost estimate of maintenance needed so that the parties associated with the school building can do preventive maintenance activities and run the maintenance of the building based on school management well was IDR 484.805.296.
\end{abstract}

\section{Introduction}

In the planning and construction process, the building has several requirements that must be fulfilled. The reliability criteria for building according to [4] is fulfilling the requirements of safety, health, comfort, and ease of building.

Damage to buildings is a sure thing to happen, both during the planning, implementation and usage period. According to [2] factors causing damage to buildings consist of building age, soil and ground water conditions, wind, earthquake, fire, lightning, material quality, pests, quality of planning, mismanagement, and changes in building functions. To maintain the condition of the building in order to keep functioning properly or in an effort to increase the form of the building and guard against damaging effects, maintenance of the building is needed. The aim of building maintenance is to preserve the building in its initial effective state and this must be started from building maintenance at organizational strategic level [12].

Building maintenance work is categorized into 3 (three), namely: (1) Rehabilitation, is to repair buildings that have been partially damaged with the intention of using certain fixed

\footnotetext{
* Corresponding author: fahirah fz@yahoo.com
} 
functions, both the architecture and structure of the building is maintained as before while the utility can change; (2) Renovation, is to repair buildings that have been partially damaged with the intention of using according to certain functions that can remain or change, both architecture, structure and utility of the building; and (3) Restoration, is to repair buildings that have been partially damaged with the intention of using for certain functions that can remain or change while maintaining the architecture of the building while the structure and utilities can change [1].

In recent years the government has made various efforts to develop facilities and infrastructure such as the construction of offices, school buildings, library buildings, classrooms and other supporting facilities such as prayer rooms and toilets. The performance of facilities in the school environment has an impact on student learning performance [8]. As facility conditions directly impact teaching and learning, it is very important for school districts to provide a healthy learning experience for quality education [10]. The relationship that exists between a principal's proficiency, creativity and management of school facilities for overall academic performance is mutually reinforcing [11].

In addition, maintenance measures were taken in the form of rehabilitation of school buildings that were damaged. Before maintenance measures in the form of rehabilitation are carried out, it is necessary to identify the level of damage that occurs in several school buildings in North Morowali District and the costs that must be incurred for building maintenance activities. Therefore, this study aims to identify the level of damage that occurs and the costs required in the maintenance of elementary school buildings in North Morowali District.

\section{Literature Review}

\subsection{Building Maintenance of Elementary School}

According to [5] elementary school buildings are government-owned buildings that functioned as a place for teaching and learning and other social activities relevant to educational programs based on the classification of government buildings, basic education buildings included in simple buildings. Meanwhile, according to [6] requirements that must be met for building buildings for elementary education units include: (1) buildings meet the standards of building arrangements; (2) fulfil safety requirements; (3) meet health requirements; (4) meet the comfort requirements; (5) providing easy, safe, and convenient facilities and accessibility including those with disabilities; (6) maximum 3 (three) floors and equipped with staircases that take into account the convenience, security, safety, and health of the user; (7) equipped with a security system; (8) equipped with electrical installations with a minimum power of 900 watts; (9) the building is designed, implemented and supervised in a professional manner; (10) the quality of the minimum permanent building of class B; (11) new school buildings can last a minimum of 20 years; and (12) meets minimum mild maintenance requirements once in 5 years and maintenance of minimum weights once in 20 years.

Activities to maintain the reliability of buildings and their facilities and infrastructure so that buildings are always function-worthy are called building maintenance efforts. The maintenance plan that has been implemented in each school [7]. Schools are important infrastructure assets that require frequent maintenance and repair of their many components and sub-components [9]. The scope of maintenance activities generally includes architectural, structural and mechanical electrical components. Architectural components consist of roof cover, roof ridge, rain gutters, floor coverings, wall coverings (plastering), ceilings, painting work, frame, locks and hangers, doors and windows. Structure components 
consist of: roof truss, concrete frame (columns and beams). Electrical mechanical components include electrical installations, plumbing systems and air conditioning installations [2].

\subsection{Damage Level and Maintenance Cost Estimation of School Building}

According to [3], concerning Guidelines for Implementation of Special Allocation Funds for Elementary School Education/Extraordinary Primary Schools states the rehabilitation standards are as follows:

1. Minor damage rehabilitation is rehabilitation of buildings with a damage level of less than $30 \%$

2. Medium damage rehabilitation is rehabilitation of buildings with a level of damage greater than $30 \%$ to $45 \%$.

3. Severely damaged rehabilitation is rehabilitation of buildings with a level of damage greater than $45 \%$ to $65 \%$.

In the case of classrooms experiencing damage of more than $65 \%$, it can be redeveloped in the form of a new space with an allocation of funds equal to the cost of building a new classroom.

Calculation of maintenance costs is carried out according to the Director General of Primary and Secondary Education Regulation. The formula used is:

Where:

$$
R=(a \times b \times c)+d
$$
R: Rehabilitation costs
a: Area of rehabilitated space
b: Value of space damage $(\%)$
c: Unit price of building/library room/teacher room per $\mathrm{m}^{2}$
$\mathrm{d}$ : Price of rehabilitation / provision of furniture

\section{Research Methods}

The technique of data collecting: 1) primary data through direct surveys in the field (case studies), and interviews to respondents namely the parties involved in the maintenance of the school building. 2) secondary data obtained from the literature, regulations related to building maintenance, journals, previous research and data from agencies related to the problem.

The research method used consists of several stages, namely:

The first stage, the preparation stage, namely 1) the survey stage and initial literature study to examine the problem through identification of damage level and building maintenance costs. 2) problem formulation and research objectives. The second stage, advanced literature review stage, namely 1 ) reviewing the results of other relevant research,2) reviewing in detail about the level of damage and building maintenance costs, 3 ) reviewing in depth the process of calculating the level of damage to buildings.

The third stage, the identification phase, which is 1) identifies damage to components from school buildings. Damage identification is obtained through site surveys and interviews with parties responsible for school buildings, 2) calculating the volume of damage to buildings and damage level. 3) calculate the cost of building maintenance based on the calculation of the volume of damage to the building.

The 4th stage, data analysis stage, namely 1) grouping the level of damage to buildings in the category of severe, medium and light damage.2) handling damage based on the level of damage. 3 ) determination of maintenance cost by type and damage volume. 
5th stage, the stages of conclusions and recommendations, namely 1) recommendations to the parties concerned about the need for school building maintenance activities. 2) the need for a budget for the maintenance of school buildings.

The data analysis process is carried out in the following ways:

1. Condition of building components

This calculation is done to determine the amount / weight of damage that occurs in each building component. To find out the damage to building components, the following equation is used:

$$
\text { Damage Weight }=\frac{\text { damage component volume }}{\text { component total volume }} \times 100 \%
$$

2. Percentage of damage

The percentage of damage to a building is calculated by accumulating all the value of damage to the component in the building. The component damage value is calculated by the formula:

Damage Value $=$ component weight for the entire building $\times$ component damage weight

3. Level of damage

The level of damage to buildings is grouped according to the following values:

1 Light Damage $<35 \%$

2 Medium Damage 35\% - 45\%

3 Weight Damage $45 \%-65 \%$

4 Total Damage $>65 \%$

4. Estimated Maintenance costs

Calculation of maintenance costs is carried out according to the Director General of Primary and Secondary Education Regulation.

\section{Results and Discussion}

\subsection{Identification of Damage Levels}

Component damage and total volume of components used are processed based on the field observation. The results of the condition of the building components of the 5 elementary schools recorded are presented in Table 1.

Table 1. Recapitulation of Condition of Elementary School Building Components

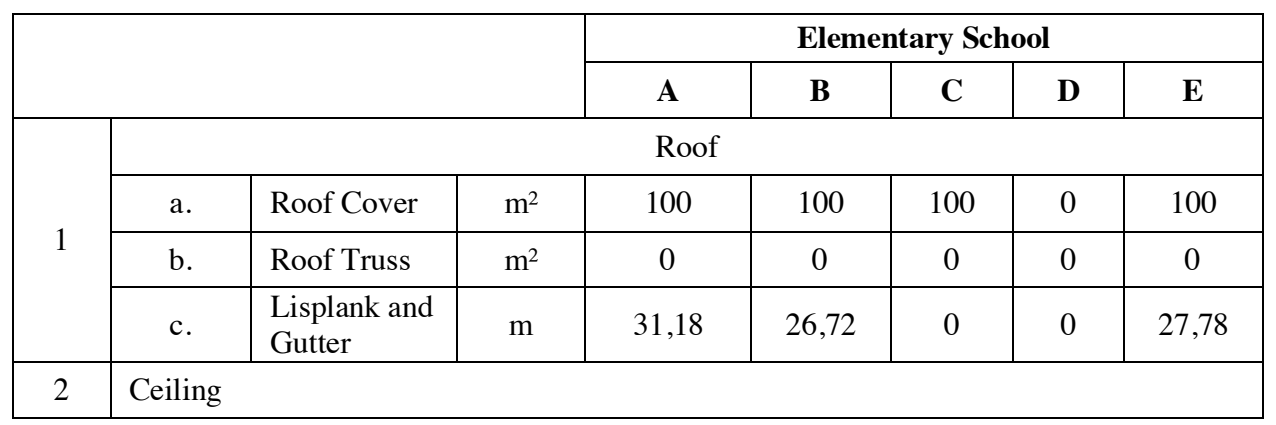




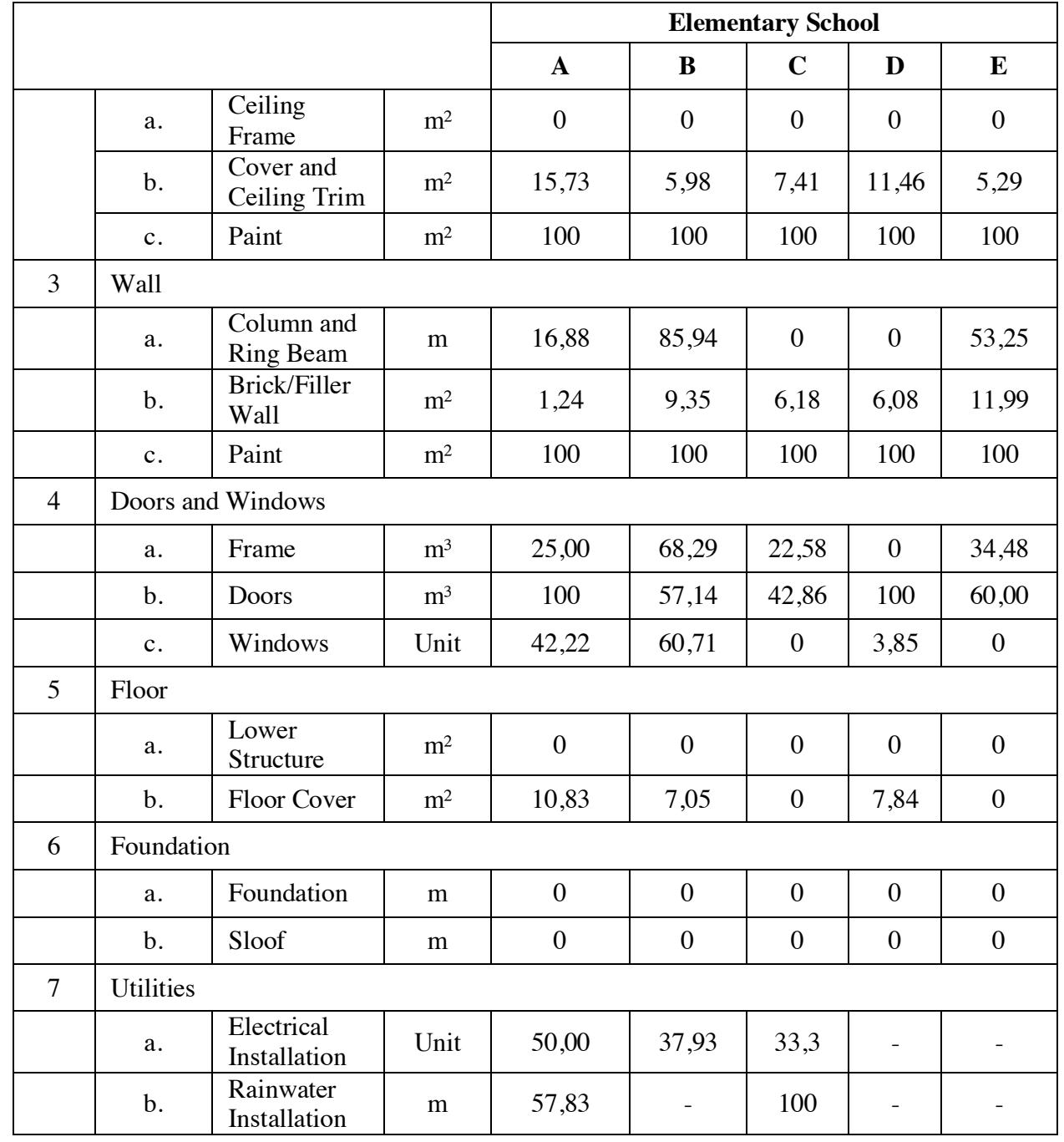

Based on Table 1 the damaged building components are the roof: lisplank and gutters, ceiling: cover and ceiling trim, walls: columns and ring beams, brick / fill walls, doors and windows: sills, doors, shutters, floors: cover floors, Utilities: electrical installations, rainwater installations. Of the five schools surveyed the components that suffered the most damage were ceiling and walls.

Table 2. Recapitulation of Damage Value of Elementary School Building

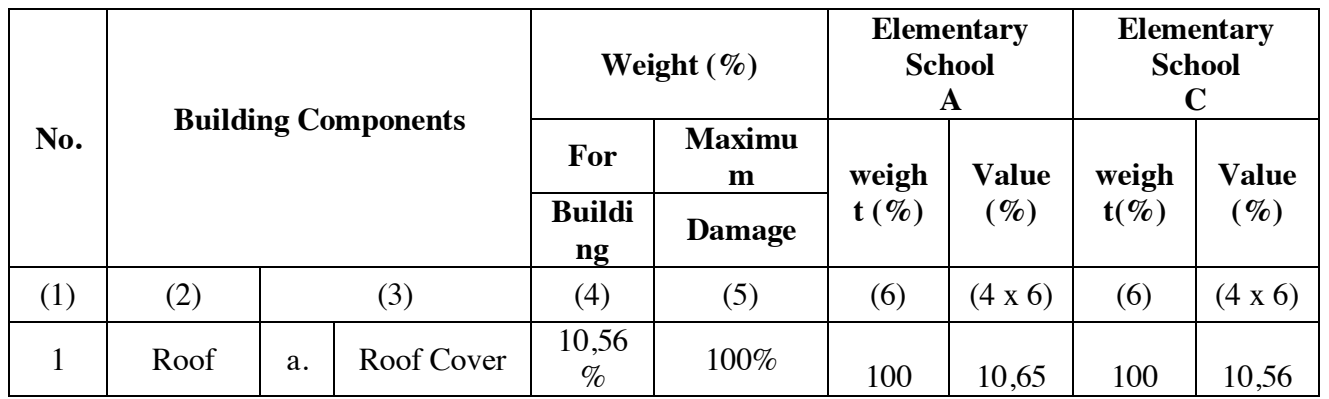




\begin{tabular}{|c|c|c|c|c|c|c|c|c|c|}
\hline & & b. & Roof Truss & $\begin{array}{c}11,62 \\
\%\end{array}$ & $100 \%$ & 0 & 0 & 0 & 0 \\
\hline & & c. & $\begin{array}{c}\text { Lisplank } \\
\text { and Gutter }\end{array}$ & $2,06 \%$ & $100 \%$ & 31,18 & 0,64 & 0 & 0 \\
\hline \multirow{3}{*}{2} & \multirow{3}{*}{ Ceiling } & a. & $\begin{array}{l}\text { Ceiling } \\
\text { Frame }\end{array}$ & $4,67 \%$ & $100 \%$ & 0 & 0 & 0 & 0 \\
\hline & & b. & $\begin{array}{c}\text { Cover and } \\
\text { Ceiling } \\
\text { Trim } \\
\end{array}$ & $5,06 \%$ & $100 \%$ & 15,73 & 0,80 & 7,41 & 0,37 \\
\hline & & c. & Paint & $1,41 \%$ & $100 \%$ & 100 & 1,41 & 100 & 1,41 \\
\hline \multirow{3}{*}{3} & \multirow{3}{*}{ Wall } & a. & $\begin{array}{l}\text { Column and } \\
\text { Ring Beam }\end{array}$ & $9,66 \%$ & $100 \%$ & 16,88 & 1,63 & 0 & 0 \\
\hline & & b. & $\begin{array}{c}\text { Brick/Filler } \\
\text { Wall }\end{array}$ & $\begin{array}{c}13,68 \\
\%\end{array}$ & $100 \%$ & 1,24 & 0,17 & 6,18 & 0,85 \\
\hline & & c. & Paint & $1,65 \%$ & $100 \%$ & 100 & 1,65 & 100 & 1,65 \\
\hline \multirow{3}{*}{4} & \multirow{3}{*}{$\begin{array}{c}\text { Doors } \\
\text { and } \\
\text { Window } \\
\mathrm{s}\end{array}$} & a. & Frame & $2,70 \%$ & $100 \%$ & 25,00 & 0,68 & 22,58 & 0,61 \\
\hline & & b. & Doors & $2,47 \%$ & $100 \%$ & 100 & 2,47 & 42,86 & 1,06 \\
\hline & & c. & Windows & $5,15 \%$ & $100 \%$ & 42,22 & 2,17 & 0 & 0 \\
\hline \multirow{2}{*}{5} & \multirow{2}{*}{ Floor } & a. & $\begin{array}{c}\text { Lower } \\
\text { Structure }\end{array}$ & $2,89 \%$ & $100 \%$ & 0 & 0 & 0 & 0 \\
\hline & & b. & Floor Cover & $8,96 \%$ & $100 \%$ & 10,83 & 0,97 & 0 & 0 \\
\hline \multirow[t]{2}{*}{6} & \multirow{2}{*}{$\begin{array}{c}\text { Foundati } \\
\text { on }\end{array}$} & a. & Foundation & $\begin{array}{c}11,15 \\
\%\end{array}$ & $100 \%$ & 0 & 0 & 0 & 0 \\
\hline & & b. & Sloof & $3,30 \%$ & $100 \%$ & 0 & 0 & 0 & 0 \\
\hline \multirow{2}{*}{7} & \multirow{2}{*}{ Utilities } & a. & $\begin{array}{c}\text { Electrical } \\
\text { Installation }\end{array}$ & $1,79 \%$ & $100 \%$ & 50,00 & 0,90 & 33,33 & 0,60 \\
\hline & & b. & $\begin{array}{l}\text { Rainwater } \\
\text { Installation }\end{array}$ & $1,22 \%$ & $100 \%$ & 57,83 & 0,71 & 100 & 1,22 \\
\hline \multicolumn{4}{|c|}{ Total (\%) } & $100 \%$ & & & 24,75 & & 18,32 \\
\hline
\end{tabular}

Table 2. Recapitulation of Damage Value of Elementary School Building (continue)

\begin{tabular}{|c|c|c|c|c|c|c|c|c|c|c|c|}
\hline \multirow{2}{*}{ No } & \multirow{2}{*}{\multicolumn{3}{|c|}{$\begin{array}{c}\text { Building } \\
\text { Components }\end{array}$}} & \multicolumn{2}{|c|}{ Weight (\%) } & \multicolumn{2}{|c|}{$\begin{array}{c}\text { Elementary } \\
\text { School } \\
\text { B }\end{array}$} & \multicolumn{2}{|c|}{$\begin{array}{c}\text { Elementary } \\
\text { School } \\
\text { D }\end{array}$} & \multicolumn{2}{|c|}{$\begin{array}{c}\text { Elementary } \\
\text { School } \\
\text { E }\end{array}$} \\
\hline & & & & $\begin{array}{c}\text { For } \\
\text { Buildin } \\
\text { g }\end{array}$ & $\begin{array}{c}\text { Maxi } \\
\text { Dama } \\
\text { ge }\end{array}$ & $\begin{array}{l}\text { weigh } \\
t(\%)\end{array}$ & $\begin{array}{c}\text { value } \\
(\%)\end{array}$ & $\begin{array}{c}\text { weight } \\
(\%)\end{array}$ & $\begin{array}{c}\text { value } \\
(\%)\end{array}$ & $\begin{array}{c}\text { weight } \\
(\%)\end{array}$ & $\begin{array}{c}\text { value } \\
(\%)\end{array}$ \\
\hline (1) & (2) & & (3) & (4) & (5) & (6) & $(4 \times 6)$ & (6) & $(4 \times 6)$ & (6) & $(4 \times 6)$ \\
\hline \multirow{3}{*}{1} & \multirow{3}{*}{ Roof } & $\mathrm{a}$ & $\begin{array}{l}\text { Roof } \\
\text { Cover }\end{array}$ & $10,56 \%$ & $100 \%$ & 100 & 10,56 & 0 & 0 & 100 & 10,56 \\
\hline & & $\mathrm{b}$ & $\begin{array}{l}\text { Roof } \\
\text { Truss }\end{array}$ & $11,62 \%$ & $100 \%$ & 0 & 0 & 0 & 0 & 0 & 0 \\
\hline & & $\mathrm{c}$ & $\begin{array}{l}\text { Lisplan } \\
\mathrm{k} \text { and } \\
\text { Gutter }\end{array}$ & $2,06 \%$ & $100 \%$ & 26,72 & 0,55 & 0 & 0 & 27,78 & 0,57 \\
\hline \multirow[b]{2}{*}{2} & \multirow[b]{2}{*}{ Ceiling } & $\mathrm{a}$ & $\begin{array}{l}\text { Ceiling } \\
\text { Frame }\end{array}$ & $4,67 \%$ & $100 \%$ & 0 & 0 & 0 & 0 & 0 & 0 \\
\hline & & b & $\begin{array}{l}\text { Cover } \\
\text { and } \\
\text { Ceiling } \\
\text { Trim }\end{array}$ & $5,06 \%$ & $100 \%$ & 5,98 & 0,30 & 11,46 & 0,58 & 5,29 & 0,27 \\
\hline
\end{tabular}




\begin{tabular}{|c|c|c|c|c|c|c|c|c|c|c|c|}
\hline & & $\mathrm{c}$ & Paint & $1,41 \%$ & $100 \%$ & 100 & 1,41 & 100 & 1,41 & 100 & 1,41 \\
\hline \multirow{3}{*}{3} & \multirow{3}{*}{ Wall } & $\mathrm{a}$ & $\begin{array}{l}\text { Colum } \\
\mathrm{n} \text { and } \\
\text { Ring } \\
\text { Beam }\end{array}$ & $9,66 \%$ & $100 \%$ & 85,94 & 8,30 & 0 & 0 & 53,25 & 5,14 \\
\hline & & $\mathrm{b}$ & $\begin{array}{l}\text { Brick/ } \\
\text { Filler } \\
\text { Wall }\end{array}$ & $13,68 \%$ & $100 \%$ & 9,35 & 1,28 & 6,08 & 0,83 & 11,99 & 1,64 \\
\hline & & $\mathrm{c}$ & Paint & $1,65 \%$ & $100 \%$ & 100 & 1,65 & 100 & 1,65 & 100 & 1,65 \\
\hline \multirow{3}{*}{4} & \multirow{3}{*}{$\begin{array}{c}\text { Doors } \\
\text { and } \\
\text { Window } \\
\mathrm{s}\end{array}$} & $\mathrm{a}$ & Frame & $2,70 \%$ & $100 \%$ & 68,29 & 1,84 & 0 & 0 & 34,48 & 0,93 \\
\hline & & $\mathrm{b}$ & Doors & $2,47 \%$ & $100 \%$ & 57,14 & 1,41 & 100 & 2,47 & 60,00 & 1,48 \\
\hline & & $\mathrm{c}$ & $\begin{array}{l}\text { Windo } \\
\text { ws }\end{array}$ & $5,15 \%$ & $100 \%$ & 60,71 & 3,13 & 3,85 & 0,20 & 0 & 0 \\
\hline \multirow[t]{2}{*}{5} & \multirow[t]{2}{*}{ Floor } & $\mathrm{a}$ & $\begin{array}{l}\text { Lower } \\
\text { Structu } \\
\text { re }\end{array}$ & $2,89 \%$ & $100 \%$ & 0 & 0 & 0 & 0 & 0 & 0 \\
\hline & & $\mathrm{b}$ & $\begin{array}{l}\text { Floor } \\
\text { Cover }\end{array}$ & $8,96 \%$ & $100 \%$ & 7,05 & 0,63 & 7,84 & 0,70 & 0 & 0 \\
\hline \multirow{2}{*}{6} & \multirow{2}{*}{$\begin{array}{l}\text { Foundat } \\
\text { ion }\end{array}$} & $\mathrm{a}$ & $\begin{array}{l}\text { Founda } \\
\text { tion }\end{array}$ & $11,15 \%$ & $100 \%$ & 0 & 0 & 0 & 0 & 0 & 0 \\
\hline & & $\mathrm{b}$ & Sloof & $3,30 \%$ & $100 \%$ & 0 & 0 & 0 & 0 & 0 & 0 \\
\hline \multirow{2}{*}{7} & \multirow{2}{*}{ Utilities } & $\mathrm{a}$ & $\begin{array}{l}\text { Electri } \\
\text { cal } \\
\text { Installa } \\
\text { tion }\end{array}$ & $1,79 \%$ & $100 \%$ & 37,93 & 0,68 & - & - & - & - \\
\hline & & $\mathrm{b}$ & $\begin{array}{l}\text { Rainw } \\
\text { ater } \\
\text { Installa } \\
\text { tion } \\
\end{array}$ & $1,22 \%$ & $100 \%$ & - & - & - & - & - & - \\
\hline \multicolumn{4}{|c|}{ Total $(\%)$} & $100 \%$ & & & 31,75 & & 7,84 & & 23,66 \\
\hline
\end{tabular}

Based on Table 2 the level of damage can be determined based on the value of component damage that occurred. The results of the classification of the damage level of the five elementary school buildings surveyed were school building A with a damage level of $24.75 \%$, school building B at $31.75 \%$, school building $\mathrm{C}$ at $18.32 \%$, school building at $7.84 \%$, and school building $\mathrm{E}$ of $23.66 \%$ obtained an average level of damage of $21.26 \%<35 \%$ with the category of minor damage. Therefore, the handling that can be done is a mild rehabilitation. The efforts carried out for minor rehabilitation are to repair building components that have been partially or completely damaged in order to continue to function properly

\subsection{Maintenance Estimation Cost}

Calculation of maintenance costs based on the predetermined formula is presented in Table 3.

Table 3. Maintenance Cost (Light Rehabilitation) Elementary School Building

\begin{tabular}{|c|c|c|c|c|}
\hline No. & Elementary School & $\begin{array}{c}\text { Wide } \\
\left(\mathbf{m}^{2}\right)\end{array}$ & $\begin{array}{c}\text { Damage } \\
\text { Level (\%) }\end{array}$ & $\begin{array}{c}\text { Maintenance } \\
\text { Cost (IDR) }\end{array}$ \\
\hline 1 & A & 192 & 24,75 & 98.040 .553 \\
\hline
\end{tabular}




\begin{tabular}{|c|c|c|c|c|}
\hline 2 & B & 240 & 18,32 & 90.737 .502 \\
\hline 3 & C & 240 & 31,75 & 157.200 .540 \\
\hline 4 & D & 128 & 7,84 & 20.709 .445 \\
\hline 5 & E & 242 & 23,66 & 118.117 .256 \\
\hline \multicolumn{2}{|r|}{ Total } & & IDR. & 484.805 .296 \\
\hline
\end{tabular}

Based on Table 3 the cost of minor rehabilitation for elementary school buildings $\mathrm{C}$ is greater (IDR. 157,200,540) than the others because the primary school building $\mathrm{C}$ also has a greater damage level $(31.75 \%)$ with the damage components are roofs, ceilings, walls, doors and windows, floors and foundations. The total cost required for light rehabilitation for the five primary school buildings is IDR. 484.805.296, - .

\section{Conclusion}

Based on the identification of the level of damage and estimated maintenance costs of the elementary school building can be concluded:

1. The average damage rate of five elementary school buildings is $21.26 \%$, the category of damage is minor damage $<35 \%$ with minor rehabilitation treatment by touching damaged building components so they can function again.

2. The cost required for handling minor rehabilitation for the five elementary school building units is IDR. 484.805.296, -.

The results of the identification of the level of damage and estimated maintenance costs of elementary school buildings are expected to help government programs in order to repair damaged school buildings and help prepare budget requirements for handling rehabilitation of school buildings, especially in North Morowali District.

\section{References}

1. Minister of Public Works Regulation No. 45 / PRT / M / 2008. About Guidelines for Building Maintenance and Maintenance, (2008).

2. Syamsuddin Jasmin, Identifikasi Kebutuhan Pemeliharaan Gedung (Studi Kasus Gedung Kantor Bupati Mamuju Utara. Essay. Engineering Faculty, Tadulako University. (2011).

3. Regulation of the Director General of Primary and Secondary Education Ministry of Education and Culture No. 04 / D / P / 2016. About the Guidelines for Implementing Special Allocation Funds in the Field of Special Education for Elementary Schools / Primary Schools. (2016).

4. Minister of Public Works and Public Housing Regulation No. 29 / PRT / M / 2006. About the Guidelines for Technical Requirements for Buildings. (2006).

5. Minister of Public Works Regulation No. 45 / PRT / M / 2007 concerning Technical Guidelines for the Construction of State Buildings. (2007).

6. Minister of Public Works Regulation No. 24 / PRT / M / 2008 concerning Guidelines for Building Maintenance and Maintenance. (2008).

7. Ropi, R. Mohammad and A.A. Tabassi, "Study on Maintenance Practices for School Buildings in Terengganu and Kedah, Malaysia", MATEC Web of Conferences, (2014). 
8. Yusoff, N.S.M; Maimunah, S; Ibrahim, S; and Masitah, M; "The Development of The Key Performance Indicators for School Classroom Facilities", International Journal of Real Estate Studies, Volume 1, Number 2, (2017).

9. Al-Bukhari, Ibraheem, "Multi-Level GIS-Based Data Management Model for Building Maintenance and Repair Data", Thesis, Civil Engineering, University of Waterloo, Waterloo, Ontario, Canada. (2008).

10. Lavy, S and David L.B, "Facilities Maintenance Management Practices in Large Public Schools, Texas", Facilities, Emerald, Volume 27, No.1/2, pp 5-20, (2009).

11. Uko, E.S, "Principalship and Effective Management of Facilities in Secondary Schools in Cross River State, Nigeria", International Journal of Academic Research and Reflection, Vol. 3, No. 1, (2015).

12. Chan, Eric, "Building Maintenance Strategy: A Sustainable Refurbishment Perspective", Universal Journal of Management 2(1): 19-25, (2014). 